\title{
PENGARUH KEPEMIMPINAN, BUDAYA ORGANISASI DAN LINGKUNGAN KERJA SERTA KEPUASAN KERJA TERHADAP KINERJA PEGAWAI WILAYAH KECAMATAN KOTA TARAKAN
}

\section{EFFECT OF LEADERSHIP, ORGANIZATIONAL CULTURE AND WORK ENVIRONMENT AND JOB SATISFACTION ON THE PERFORMANCE OF EMPLOYEES AREA DISTRICT CITY TARAKAN}

\author{
Ana Sriekaningsih \\ Sekolah Tinggi Ilmu Ekonomi Bulungan Tarakan \\ Jl. Gunung Amal Kampung Enam Tarakan \\ Email :an_juf19@yahoo.co.id
}

Naskah diterima: 17 Februari 2017, revisi pertama: 1 Maret 2017, revisi kedua: 9 Maret 2017, revisi ketiga: 27 April 2017, disetujui 29 April 2017.

\begin{abstract}
The purpose of this study is to determine the significance of the influence of the leadership, organizational culture and work environment to employee performance and job satisfaction as an intervening variable. The research population is all employees in the District of the City of Tarakan, with a sample of 128 employees. Data analysis method used in this research is path analysis.The research findings show that leadership, organizational culture and work environment had positive and significant impact on employee performance. The second discovery revealed that the leadership, work environment and job satisfaction held significant positive effect on employee performance, whereas the organizational culture had significant negative effect on employee performance. Results of path analysis showed that:(1) Job satisfaction is proven as an intervening variable between leadership a direct influence on employee performance is more dominant than the indirect effect. (2) Job satisfaction is proven as an intervening variable indirect influence of organizational culture on employee performance is more dominant than the direct effect. (3) Job satisfaction is proven as an intervening variable indirect influence among the working environment is more dominant than the direct effect.
\end{abstract}

Keywords: leadership, organizational culture, working environment, job satisfaction, employee performance 


\begin{abstract}
Abstrak
Tujuan dari penelitian ini adalah untuk menentukan pengaruh signifikansi kepemimpinan, budaya organisasi dan lingkungan kerja terhadap kinerja pegawai dan kepuasan kerja sebagai variabel antara. Populasi penelitian ini adalah seluruh pegawai di Kecamatan Kota Tarakan, dengan sampel 128 pegawai. Metode analisis data yang digunakan adalah analisis jalur. Temuan penelitian menunjukkan bahwa kepemimpinan, budaya organisasi dan lingkungan kerja yang positif dan signifikan terhadap kinerja pegawai. Penemuan kedua diketahui bahwa kepemimpinan, lingkungan kerja dan kepuasan kerja dan berpengaruh positif signifikan terhadap kinerja pegawai, sedangkan budaya organisasi dan berpengaruh negatif terhadap kinerja pegawai. Hasil analisis jalur menunjukkan bahwa: (1) Kepuasan kerja terbukti sebagai variabel antara variabel kepemimpinan pengaruh langsung terhadap kinerja pegawai lebih dominan daripada pengaruh tidak langsung. (2) Kepuasan kerja terbukti sebagai variabel antara pengaruh tidak langsung variabel budaya organisasi terhadap kinerja pegawai lebih dominan daripada berpengaruh langsung. (3) Kepuasan kerja terbukti sebagai variabel antara pengaruh tidak langsung variabel lingkungan kerja yang lebih dominan daripada berpengaruh efek langsung.
\end{abstract}

Kata kunci: kepemimpinan, budaya organisasi, lingkungan kerja, kepuasan kerja, kinerja pegawai

\title{
A. PENDAHULUAN
}

Pemerintah wilayah kecamatan Kota Tarakan sebagai institusi public service yang memiliki fungsi pelayanan tentunya mempunyai akses besar dan tampaknya tidak terlepas dari perannya dalam menyikapi fenomena pengelolaan sumberdayanya, sehingga kinerja instansi maupun para pegawai menjadi tuntutan utama dalam memberikan pelayanan kepada masyarakat secara efektif dan efisien. Saat ini kinerja pegawai wilayah Kecamatan Kota Tarakan membantu pemerintah dalam mewujudkan visi, misi, dan kebijakan pembangunan daerah disegala bidang. Kinerja pegawainya dapat terlihat dari rendahnya angka ketidakhadiran pegawai, disiplin masuk kerja pegawai sudah baik, pembagian tugas sudah jelas, jenis-jenis pelayanan telah dilakukan dengan baik, dan kecepatan pelayanan dapat memuaskan masyarakat yang mendapatkan pelayanan.

Sutrisno (2012: 151) menyebutkan bahwa kinerja pegawai dipengarui oleh banyak faktor diantaranya adalah budaya organisasi dan lingkungan kerja. Budaya organisasi merupakan suatu kekuatan sosial yang tidak tampak, yang dapat menggerakkan orang-orang dalam suatu lingkungan kerja untuk melakukan aktivitas kerja. Aktivitas kerja pegawai dapat berjalan dengan baik apabila dipemimpin oleh pemimpinan yang tepat. Berdasarkan pendapat Sutrisno tersebut penulis berargumen bahwa kinerja pegawai dipengaruhi oleh banyak faktor, diantaranya kepemimpinan, budaya organisasi dan lingkungan kerjanya, sehingga masih ada pegawai yang merasa belum puas dengan hasil kerjanya. Guna mendukung kinerja pegawai maka perlu meningkatkan SDMnya, kualitas pelayanan pada masyarakat dan lembaga masyarakat. Kepemimpinan kantor Kecamatan Kota Tarakan dalam pelaksanaan tugasnya dibantu oleh perangkat pegawai di Kecamatan yang bertanggungjawab pada Kepala Daerah. Camat dalam melaksanakan kepemimpinannya lebih menekankan diri sebagai fasilitator yang memfasilitasi kebutuhan masyarakat di daerahnya masing-masing, Sedangkan tipe kepemimpinan yang digunakan lebih bersifat demokratis.

Budaya organisasi Pemerintah wilayah kecamatan Kota Tarakan pada saat ini berorientasi pada kepuasan publik, sehingga pemerintah berupaya memenuhi harapan pegawai, sehingga para 
pegawai mendapatkan kepuasan kerja dalam kerjanya. Sesuai pernyataan Sedarmayanti (2012: 154) apabila pegawai merasa puas dengan hasil kerjanya maka kinerjanyapun akan meningkat. Selain budaya kerja faktor lingkungan kerja berarti penting bagi pegawai dalam melakukan aktivitas, karena hal ini akan menentukan secara langsung maupun tidak langsung dalam mewujudkan visi dan misi yang akan dicapai. Para pegawai saat ini telah merasakan bahwa lingkungan kerjanya menyenangkan sesuai dengan kebutuhan yang diinginkan.

Berdasarkan uraian di atas, penulis mengkajinya dalam bentuk penelitian dengan memfokuskan pada masalah:

1. Bagaimana pengaruh kepemimpinan terhadap kepuasan kerja pegawai?

2. Bagaimana pengaruh budaya organisasi terhadap kepuasan kerja pegawai?

3. Bagaimana pengaruh lingkungan kerja terhadap kepuasan kerja pegawai?

4. Bagaimana pengaruh kepemimpinan terhadap kinerja pegawai?

5. Bagaimana pengaruh budaya organisasi terhadap kinerja pegawai?

6. Bagaimana pengaruh lingkungan kerja terhadap kinerja pegawai?

7. Bagaimana pengaruh kepuasan kerja terhadap kinerja pegawai pegawai?

Dengan penjabaran latar belakang dan permasalahan yang ada dapat ditentukan bahwa tujuan dari penelitian ini adalah untuk mengetahui pengaruh kepemimpinan, budaya organisasi dan lingkungan kerja serta kepuasan kerja terhadap kinerja pegawai wilayah Kecamatan Kota Tarakan. Adapun manfaat yang akan diperoleh antara lain informasi yang lebih banyak tentang ilmu manajemen sumber daya manusia khususnya mengenai kepemimpinan, budaya organisasi, lingkungan kerja yang mempengaruhi kepuasan kerja dan kinerja pegawai.

\section{B. METODE PENELITIAN}

Penelitian ini merupakan penelitian korelasional. Dalam penelitian ini yang menjadi populasi adalah seluruh pegawai Wilayah Kecamatan Kota Tarakan yang berjumlah sebanyak 128 pegawai yang meliputi dari pegawai di empat Kecamatan yang ada di Kota Tarakan. Teknik sampling yang dipakai dalam penelitian ini adalah teknik sensus yaitu seluruh populasi penelitian dijadikan sampel penelitian Sugiyono (2012: 85). Data yang digunakan dalam penelitian ini adalah jenis data primer yaitu data yang diperoleh langsung dari sumbernya, diamati dan dicatat untuk pertama kali. Data primer ini berupa jawaban angket atau kuesioner dari sampel penelitian. Metode pengumpulan data penelitian adalah survey langsung dan angket dengan skala Likert. Teknik analisis data menggunakan path analysis.

\section{KERANGKA KONSEP}

Kinerja

Menurut Mangkunegara(2011:9) kinerja dapat didefinfisikan sebagai hasil kerja secara kualitas dan kuantitas yang dapat dicapai oleh seseorang pegawai dalam melaksanakan tugas sesuai dengan tanggung jawab yang diberikan kepadanya. Kinerja adalah kemampuan yang dimiliki seseorang dalam bidangnya, adanya usaha yang tinggi untuk mencapai target tertentu dalam pekerjaan, dan adanya persepsi yang jelas tentang peran manajer dalam pencapaian tujuan Mulyadi (2011: 98). Kinerja merupakan hasil atau tingkatan keberhasilan seseorang secara keseluruhan selama periode tertentu dalam melaksanakan tugas dibandingkan dengan standar hasil kerja, target atau sasaran atau kriteria yang telah ditentukan terlebih dahulu dan telah disepakati bersama Rivai (2010:53). 
Sudarmanto (2012: 12) menyebutkan 6 kriteria yang dapat digunakan untuk mengukur kinerja pegawai secara individu yakni :

1. Kualitas. Hasil pekerjaan yang dilakukan mendekati sempurna atau memenuhi tujuan yang diharapkan dari pekerjaan tersebut.

2. Kuantitas. Jumlah yang dihasilkan atau jumlah aktivitas yang dapat diselesaikan.

3. Ketepatan waktu, yaitu dapat menyelesaikan pada waktu yang telah ditetapkan serta memaksimalkan waktu yang tersedia untuk aktivitas yang lain.

4. Efektivitas. Pemanfaatan secara maksimal sumber daya yang ada pada organisasi untuk meningkatkan keuntungan dan mengurangi kerugian.

5. Kemandirian, yaitu dapat melaksanakan kerja tanpa bantuan guna menghindari hasil yang merugikan.

6. Komitmen kerja, yaitu komitmen kerja antara pegawai dengan organisasinya.

7. Tanggung jawab pegawai terhadap organisasinya.

\section{Kepemimpinan}

Menurut Suradji dan Martono (2014:15), kepemimpinan adalah proses untuk mempengaruhi orang lain, untuk memahami dan setuju dengan apa yang perlu dilakukan dan bagaimana tugas itu dilakukan secara efektif, serta proses untuk memfasilitasi upaya individu dan kolektif untuk mencapai tujuan bersama. Menurut Sutrisno (2012: 213) kepemimpinan adalah suatu proses kegiatan seseorang untuk menggerakkan orang lain, untuk melakukan sesuatu agar dicapai hasil yang diharapkan. Menurut Nanus (2012: 14) ada 4 peran kritis dari kepemimpinan yang efektif, yaitu:

1. Mengarahkan

Pemimpin memilih dan mengartikulasikan sasaran dalam lingkungan eksternal ke depan (dalam arti mempunyai visi). Untuk membuat arahan yang baik, pemimpin harus dapat mengeset tujuan ke depan yang diakui sebagai bentuk perwakilan yang nyata dari kemajuan organisasi.

2. Agen perubahan

Pemimpin bertanggung jawab menjadi katalisator perubahan dalam lingkungan intern, misalnya dalam masalah personalia, sumber daya dan fasilitas untuk pencapaian visi ke depan. Untuk menjadi agen perubahan yang baik, maka pemimpin harus dapat mengantisipasi pembangunan luar yang memberikan dampak terhadap organisasi. Sebagai pemimpin harus mempunyai keahlian dan kewenangan secara langsung dan tidak langsung untuk mengarahkan perubahan.

3. Juru bicara

Pemimpin harus memiliki keahlian bicara, konsentrasi menjadi pendengar dan sangat perhatian terhadap visi organisasi. Untuk menjadi juru bicara yang efektif, pemimpin terutama sebagai nagasiator dan melakukan lobi dengan organisasi lain dan membangun jaringan kerja hubungan eksternal untuk menyediakan kegunaan gagasan, sumber daya, dukungan dan informasi.

4. Membimbing

Pemimpin adalah pembentuk tim yang memberdayakan individu dalam organisais dan hidup dalam visi, dengan demikian pemimpin melayani sebagai pembimbing dan usaha membuat visi menjadi kenyataan. Untuk menjadi pembimbing yang efektif, pemimpin harus membiarkan orang/ bawahan untuk mengetahui dimana pemimpin berada, apa arti visi bagi pemimpin, dan akan membuat apa yang terjadi dari visi tersebut. Pemimpin harus mempunyai komitmen untuk meraih keberhasilan setiap orang dalam organisasi.

Berdasarkan beberapa pendapat diatas dapat disimpulkan bahwa kepemimpinan adalah proses mengarahkan, membimbing dan mempengaruhi pikiran, perasaan, tindakan dan tingkah laku orang lain untuk digerakkan ke arah tujuan tertentu. 


\section{Budaya Organisasi}

Budaya organisasi selanjutnya menjadi identitas atau karakter utama organisasi yang dipelihara dan dipertahankan (Mas'ud, 2010:52). Suatu budaya yang kuat merupakan perangkat yang sangat bermanfaat untuk mengarahkan perilaku, karena membantu pegawai untuk melakukan pekerjaan yang lebih baik sehingga setiap pegawai pada awal karirnya perlu memahami budaya dan bagaimana budaya tersebut terimplementasikan.

Menurut McKenna dan Nic Beech dalam Sutrisno (2012:241) budaya organisasi adalah sebagai pola asumsi-asumsi yang mendasar di mana kelompok yang ada menciptakan, menemukan atau berkembang dalam proses belajar untuk menanggulangi kesulitan-kesulitan adaptasi eksternal dan integrasi internal. Schein (2011:85) menyatakan bahwa budaya organisasi adalah pola asumsi dasar bersama yang dipelajari oleh kelompok saat memecahkan masalah-masalah adaptasi ekstern dan integrasi internal yang telah berfungsi dengan cukup baik untuk bisa dianggap benar dan untuk bisa diajarkan kepada anggota kelompok baru sebagai cara yang benar untuk menerima sesuatu, berfikir dan merasakan dalam hubungannya dengan masalah-masalah tersebut.

Sedangkan Luthans (2012: 321), menyatakan budaya organisasi mempunyaisejumlah karakteristik penting, diantaranya adalah:

a. Aturan perilaku yang diamati. Ketika anggota organisasi berinteraksi satu sama lain, mereka menggunakan bahasa, istilah, dan ritual umum yang berkaitan dengan rasa hormat dan cara berperilaku.

b. Norma. Adalah standar perilaku, mencakup pedoman mengenai seberapa banyak pekerjaan yang dilakukan, yang dalam banyak perusahaan menjadi "jangan melakukan terlalu banyak; jangan terlalu sedikit”.

c. Nilai dominan. Organisasi mendukung dan berharap peserta membagikannilai-nilai utama. Contohnya adalah kualitas produk tinggi, sedikit absen, danefisiensi tinggi.

d. Filosofi. Terdapat kebijakan yang membentuk kepercayaan organisasimengenai bagaimana karyawan dan atau pelanggan diperlakukan.

e. Aturan. Terdapat pedoman ketat berkaitan dengan pencapaian perusahaan.Pendatang baru harus mempelajari teknik dan prosedur yang ada agar diterimasebagai anggota kelompok yang berkembang.

f. Iklim Organisasi. Merupakan keseluruhan "perasaan” yang disampaikan dengan pengaturan baru yang bersifat fisik, cara peserta berinteraksi, dan cara anggota organisasi berhubungan dengan pelanggan dan individu dari luar.

\section{Lingkungan Kerja}

Kemudian Sedarmayanti (2012:183) mengemukakan lingkungan kerja adalah segala yang ada di sekitar para pekerja yang dapat mempengaruhi dirinya dalam menjalankan tugas yang dibebankan. Pendapat lain mengatakan lingkungan kerja adalah keadaan fisik dimana seseorang melakukan tugas kewajibannya sehari-hari termasuk kondisi ruang yaitu baik dari kantor maupun pabrik (Siagian, 2012:139) Menurut Supardi (2011:25) lingkungan kerja merupakan keadaan sekitar tempat kerja baik secara fisik maupun non fisik yang dapat memberikan kesan menyenangkan mengamankan, menentramkan dan kesan krasan atau betah bekerja dan lain sebagainya. Menurut Siagian (2012:37) lingkungan kerja adalah suatu lingkungan dimana kerja bekerja sedangkan kondisi kerja merupakan kondisi dimana pegawai tersebut bekerja. Kondisi kerja termasuk salah satu unsur lingkungan kerja, sebab lingkungan kerja di dalam organisasi/kelembagaan bukan hanya terdiri dari kondisi kerja sama, tetapi bila kondisi kerja ditambah beberapa aspek lain maka akan membentuk lingkungan kerja. 
Menurut Nitisemito (2012: 63) lingkungan kerja adalah segala sesuatu yang ada disekitar pegawai yang mempengaruhi hasil tugas-tugas yang dibebankan. Faktor-faktor yang dapat termasuk lingkungan kerja yang harus diketahui dan diperhatikan yang berpengaruh besar terhadap semangat dan kegairahan kerja antara lain : (1) pewarnaan, (2) kebersihan, (3) pertukaran udara, (4) penerangan, (5) musik, (6) keamanan dan (7) kebisingan. Lingkungan kerja yang memenuhi syarat sebagaimana diatas dapat membuat pegawai merasa nyaman senang betah bekerja dan memiliki gairah kerja yang bertambah sehingga dapat menaikkan kinerja.

Terdapat bermacam-macam faktor yang mempengaruhi lingkungan kerjadimana kegiatan dilaksanakan, yaitu (Sarwoto, 2011: 131):

a. Perlengkapan dan fasilitas

b. Suasana kerja (non physical working environment)

c. Lingkungan tempat kerja (physical working environment)

\section{Kepuasan Kerja}

Sedangkan definisi kepuasan kerja menurut Handoko (2010: 193) kepuasan kerja merupakan keadaan emosional yang menyenangkan atau tidak menyenangkan dengan para pegawai memandang pekerjaan mereka, kepuasan kerja mencerminkan perasaan seseorang terhadap pekerjaannya.Baron, R. A \& Greenberg, J (2008:161) mendeskripsikan kepuasan kerja sebagai sikap positif atau negatif yang dilakukan individu terhadap pekerjaan mereka. Selain itu Gibson (2009:62) menyatakan kepuasan kerja sebagai sikap yang dimiliki para pekerja tentang pekerjaan mereka. Hal itu merupakan hasil dari persepsi mereka tentang pekerjaan.

Harold E. Burt dalam As’ad (2015: 112) mengemukakan pendapatnya tentang faktor-faktor yang dapat menimbulkan kepuasan kerja antara lain :

a. Faktor hubungan antar karyawan, antara lain hubungan antara pimpinan dengan karyawan, faktor fisik dan kondisi kerja, hubungan sosial diantara karyawan, sugesti dari teman kerja, emosi dan situasi kerja.

b. Faktor individual, antara lain sikap kerja seseorang terhadap pekerjaannya, umur orang sewaktu bekerja, serta jenis kelamin karyawan.

c. Faktor-faktor dari luar (ekstern) antara lain keadaan keluarga karyawan, rekreasi, pendidikan (training, up grading dan lain-lain).

Sedangkan menurut pendapat Gilmer dalam As’ad (2015 : 114) tentang faktor-faktor yang mempengaruhi kepuasan kerja sebagai berikut :

a. Kesempatan untuk maju.

Dalam hal ini ada tidaknya kesempatan untuk memperoleh kesempatan peningkatan pengalaman dan kemampuan kerja selama bekerja.

b. Keamanan kerja.

Faktor ini sering disebut sebagai penunjang kepuasan kerja, baik karyawan pria maupun wanita.

Keadaan yang aman sangat mempengaruhi perasaan kerja karyawan selama bekerja.

c. Gaji

Gaji lebih banyak menyebabkan ketidakpuasan, dan jarang orang yang mengekspresikan kepuasan kerjanya dengan sejumlah uang yang diperolehnya.

d. Manajemen kerja.

Manajemen kerja yang baik adalah yang memberikan situasi dan kondisi kerja yang stabil, sehingga karyawan dapat bekerja dengan nyaman. 
e. Kondisi kerja.

Dalam hal ini adalah tempat kerja, ventilasi, penyinaran, kantin, dan tempat parkir.

f. Komunikasi.

Komunikasi yang lancar antara karyawan dengan pimpinan banyak dipakai untuk menyukai jabatannya. Dalam hal ini adanya kesediaan pihak pimpinan untuk mau mendengar, memahami dan mengakui pendapat atau prestasi karyawannya sangat berperan dalam menimbukan kepuasan kerja.

Menurut pendapat As’ad (2015:115), faktor yang mempengaruhi kepuasan kerja antara lain :

a. Faktor psikologis, merupakan faktor yang berhubungan dengan kejiwaan pegawai yang meliputi minat, ketentraman kerja, sikap terhadap kerja, perasaan kerja.

b. Faktor fisik, merupakan faktor yang berhubungan dengan fisik lingkungan kerja dan kondisi fisik pegawai, meliputi jenis pekerjaan, pengaturan waktu kerja, perlengkapan kerja, sirkulasi udara, kesehatan pegawai.

c. Faktor finansial, merupakan faktor yang berhubungan dengan jaminan serta kesejahteraan pegawai, yang meliputi sistem penggajian, jaminan sosial, besarnya tunjangan, fasilitas yang diberikan, promosi dan lain-lain.

Kepuasan kerja berkaitan dengan fisik dalam melaksanakan tugas-tugas pekerjaannya, kondisi lingkungan pekerjaannya, ia juga berkaitan dengan interaksinya dengan sesama rekan kerjanya, serta sistem hubungan diantara mereka. Ketidakpuasan kerja dalambanyak hal sering dimanifestasikan dalam tindakan-tindakan destruktif aktifdan pasif, seperti suka mengeluh, menjadi tidak patuh terhadap peraturan,tidak berusaha menjaga aset perusahaan, membiarkan hal-hal buruk terusterjadi, dan menghindar dari tanggung jawabnya.

Kerangka konseptual dalam bagan yang menunjukkan arah pengaruh variabel bebas terhadap variabel terikat.

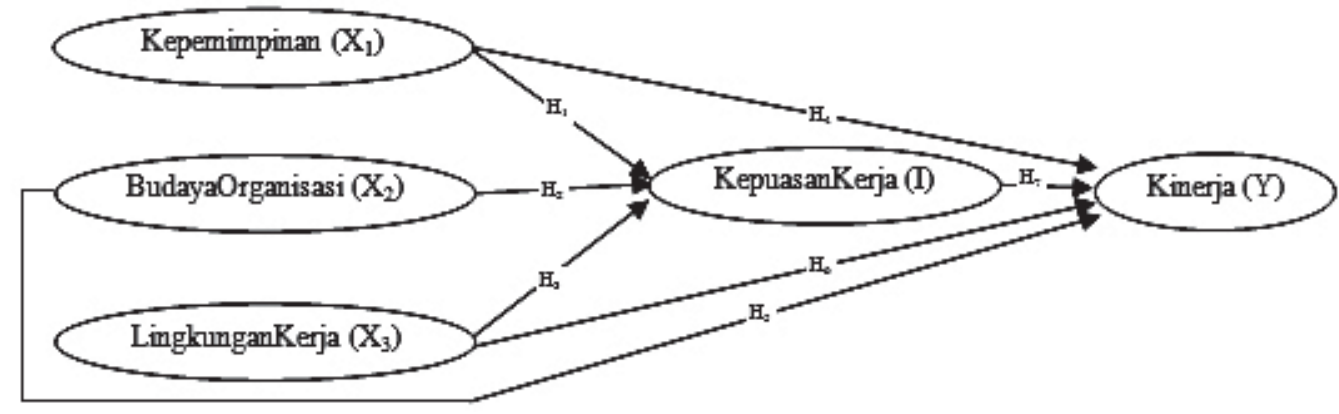

Hipotesis dalam penelitian ini adalah sebagai berikut:

H1 : Terdapat pengaruh kepemimpinan terhadap kepuasan kerja pegawai.

H2 : Terdapat pengaruh budaya organisasi terhadap kepuasan kerja pegawai.

H3 : Terdapat pengaruh lingkungan kerja terhadap kepuasan kerja pegawai.

H4: Terdapat pengaruh kepemimpinan terhadap kinerja pegawai.

H5: Terdapat pengaruh budaya organisasi terhadap kinerja pegawai.

H6 : Terdapat pengaruh lingkungan kerja terhadap kinerja pegawai.

H7 : Terdapat pengaruh kepuasan kerja pada kinerja pegawai pegawai. 


\section{HASIL DAN PEMBAHASAN}

Karakteristik responden berupa identitas dari masing-masing responden mengenai usia, jenis kelamin, pendidikan terakhir, masa kerja dan golongan. Hasil penyebaran data atau kuesioner disajikan berupa data mentah yang diolah menggunakan teknik statistik deskripsi. Sampel yang diambil data dalam penelitian ini adalah 128 pegawai.

Berdasarkan uji instrumen penelitian dalam uji validitas dengan pengujian menggunakan one shot methods maksudnya adalah melakukan penyebaran kuesioner pada responden hanya satu kali dan diketahui dari 9 item pernyataan tentang kepemimpinan semuanya valid, dari 10 item pernyataan tentang budaya organisasi semuanya valid, dari 10 item pernyataan tentang lingkungan kerja semuanya valid, dari 8 item pernyataan tentang kepuasan kerja semuanya valid, dan dari 12 item pernyataan tentang kinerja semuanya valid, karena nilai $r_{\text {hitung }}>\mathrm{r}_{\text {tabel }}$. Hasil uji reliabilitas seluruh variabel penelitian dinyatakan reliable karena memiliki nilai Cronbach's Alpha > 0,6, yaitu Kepemimpinan $\left(X_{1}\right)=0,850$; Budaya organisasi $\left(X_{2}\right)=0,856$; Lingkungan kerja $\left(X_{3}\right)=0,857$; Kepuasan kerja $\left(\mathrm{X}_{4}\right)=0,831$; dan $\operatorname{Kinerja~}(\mathrm{Y})=0,902$.

Setelah dilakukan uji instrument kemudian dilakukan uji asumsi klasik diperlukan untuk mengetahui apakah hasil estimasi regresi yang dilakukan benar-benar bebas dari adanya gejala heteroskedastisitas, gejala multikolinearitas, dan gejala autokorelasi.

1. Hasil Uji Normalitas diketahui grafik normal probability plots menunjukkan titik-titik menyebar berhimpitan di sekitar garis diagonal dan hal ini menunjukkan bahwa residual terdistribusi secara normal.

2. Hasil Uji Multikolinieritas diketahui nilai tolerance dari masing-masing lebih dari 0,10 (kepemimpinan :0,245; budaya organisasi : 0,297; lingkungan kerja : 0,152; dan kepuasan kerja :0,106) serta nilai VIF kurang dari 10,0 (kepemimpinan :4,083; budaya organisasi :3,363; lingkungan kerja :6,592; dan kepuasan kerja :9,434) yang berarti lolos multikolinieritas

3. Hasil Uji Heteroskedastisitas diketahui grafik scatterplots diketahui titik-titik menyebar secara acak (random) baik diatas maupun di bawah angka 0 pada sumbu Y. hal ini dapat disimpulkan bahwa tidak terjadi heteroskedastisitas pada model regresi.

4. Hasil Uji Autokorelasi diketahui Nilai DW 1,907 < 4-dU = 2,242 dapat disimpulkan tidak terdapat autokorelasi pada model regresi.

Setelah seluruh variabel penelitian diketahui lolos dari gangguan linier dengan uji asumsi klasik, kemudian dilakukan uji hipotesis dengan analisis jalur (path analysis). Dalam uji hipotesis ini dilakukan dua kali uji regresi, yaitu:

Tabel 1

Analisis Pertama

\begin{tabular}{lrrrr}
\hline \multicolumn{1}{c}{ Model } & $\begin{array}{c}\text { Unstandardized } \\
\text { Coefficients } \\
\text { B }\end{array}$ & $\begin{array}{c}\text { Standardized } \\
\text { Coefficients } \\
\text { Beta }\end{array}$ & t & Sig \\
\hline Konstanta (a) & $-1,772$ & & $-1,503$ & 0,135 \\
Kepemimpinan $\left(\mathrm{X}_{1}\right)$ & 0,303 & 0,324 & 6,304 & 0,000 \\
Budayaorganisasi (X) & 0,096 & 0,126 & 2,409 & 0,017 \\
Lingkungankerja $\left(\mathrm{X}_{3}\right)$ & 0,468 & 0,557 & 9,942 & 0,000 \\
\hline Dependent variable - KepuasanKerja & & & &
\end{tabular}


Persamaan Pertama X4 = -1,772 + 0,324 X1 + 0,126 X2 + 0,557 X3.

Diketahui Nilai variance yang tidak dapat dijelaskan oleh variabel kepuasan kerja:

$$
e_{1}=\sqrt{1-R^{2}}=\sqrt{1-0,894}=0,326
$$

1. Pengaruh Kepemimpinan Terhadap Kepuasan Kerja Pegawai

Berdasarkan Tabel 1 menunjukkan bahwa $t_{\text {hitung }}$ variabel kepemimpinan sebesar 6,304 dengan nilai signifikansi sebesar 0,000 dan lebih kecil dari 0,05, maka dapat disimpulkan bahwa terdapat pengaruh yang positif dan signifikan antara variabel kepemimpinan terhadap kepuasan kerja, sehingga hipotesis 1 terbukti dalam penelitian ini.

2. Pengaruh Budaya Organisasi Terhadap Kepuasan Kerja Pegawai

Berdasarkan Tabel 1menunjukkan bahwat ${ }_{\text {hitung }}$ variabel budaya organisasi sebesar 2,409 dengan nilai signifikansi sebesar 0,017 dan lebih kecil dari 0,05, maka dapat disimpulkan bahwa terdapat pengaruh yang positif dan signifikan antara variabel budaya organisasi terhadap kepuasan kerja, sehingga hipotesis 2 terbukti dalam penelitian ini.

3. Pengaruh Lingkungan Kerja Terhadap Kepuasan Kerja Pegawai

Berdasarkan Tabel 1 menunjukkan bahwa thitung variabel lingkungan kerja sebesar 9,942 dengan nilai signifikansi sebesar 0,000 dan lebih kecil dari 0,05, maka dapat disimpulkan bahwa terdapat pengaruh yang positif dan signifikan antara variabel lingkungan kerja terhadap kepuasan kerja, sehingga hipotesis 3 terbukti dalam penelitian ini.

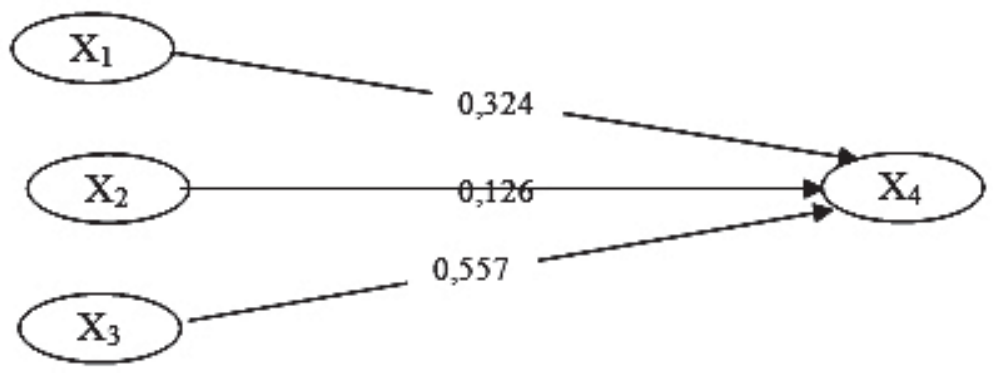

Tabel 2

Analisis Kedua

\begin{tabular}{lrrrr}
\hline \multicolumn{1}{c}{ Model } & $\begin{array}{c}\text { Unstandardized } \\
\text { Coefficients } \\
\text { B }\end{array}$ & $\begin{array}{c}\text { Standardized } \\
\text { Coefficients } \\
\text { Beta }\end{array}$ & t & Sig \\
\hline Konstanta (a) & $-3,179$ & & $-1,685$ & 0,095 \\
Kepemimpinan $\left(\mathrm{X}_{1}\right)$ & 0,914 & 0,636 & 10,439 & 0,000 \\
Budayaorganisasi $\left(\mathrm{X}_{2}\right)$ & $-0,188$ & $-0,161$ & $-2,917$ & 0,004 \\
Lingkungankerja $\left(\mathrm{X}_{3}\right)$ & 0,221 & 0,171 & 2,210 & 0,029 \\
Kepuasankerja $\left(\mathrm{X}_{4}\right)$ & 0,481 & 0,313 & 3,378 & 0,001 \\
\hline
\end{tabular}

\section{Dependent variable kinerjapegawai}

Persamaaan Y = -3,179 + 0,636 X1 - 0,161 X2 + 0,171 X3 + 0,313 X4

Diketahui nilai variance yang tidak dapat dijelaskan oleh variabel kinerja adalah:

$e_{2}=\sqrt{1-R^{2}}=\sqrt{1-0,888}=0,335$ 
4. Pengaruh Kepemimpinan Terhadap Kinerja Pegawai

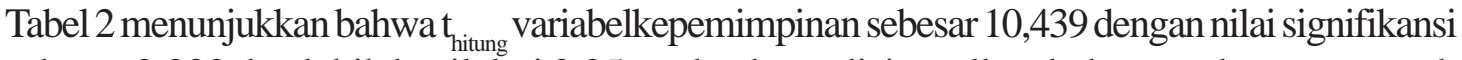
sebesar 0,000 dan lebih kecil dari 0,05, maka dapat disimpulkan bahwa terdapat pengaruh yang positif dan signifikan antara variabel kepemimpinan kerja terhadap kinerja pegawai, sehingga hipotesis 4 terbukti dalam penelitian ini.

5. Pengaruh Budaya Organisasi Terhadap Kinerja Pegawai

Tabel 2 menunjukkan bahwa $t_{\text {hitung }}$ variabelbudaya organisasi sebesar -2,917 dengan nilai signifikansi sebesar 0,004 dan lebih kecil dari 0,05, maka dapat disimpulkan bahwa terdapat pengaruh yang negatif dan signifikan antara variabel budaya organisasi terhadap kinerja pegawai, sehingga hipotesis 5 terbukti dalam penelitian ini.

6. Pengaruh Lingkungan Kerja Terhadap Kinerja Pegawai

Tabel 2 menunjukkan bahwa thitung variabellingkungan kerja sebesar 2,210 dengan nilai signifikansi sebesar 0,029 dan lebih kecil dari 0,05, maka dapat disimpulkan bahwa terdapat pengaruh yang positif dan signifikan antara variabel lingkungan kerja terhadap kinerja pegawai, sehingga hipotesis 6 terbukti dalam penelitian ini.

7. Pengaruh Kepuasan Kerja Pada Kinerja Pegawai Pegawai

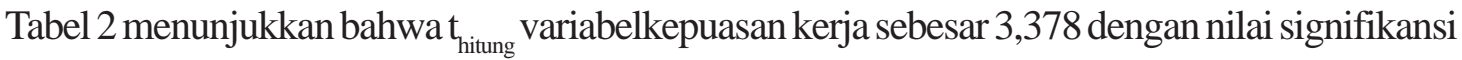
sebesar 0,001 dan lebih kecil dari 0,05, maka dapat disimpulkan bahwa terdapat pengaruh yang positif dan signifikan antara variabel kepuasan kerja terhadap kinerja pegawai, sehingga hipotesis 7 terbukti dalam penelitian ini.

Setelah diketahui nilai variance dari kedua persamaan, maka diketahui nilai koefisien determinasi $\left(\mathrm{R}^{2}\right)=1-\left(\mathrm{e}_{1} \mathrm{x} \mathrm{e}_{2}\right)=0,988$ atau $98,9 \%$

Uji koefisien determinasi $\left(\mathrm{R}^{2}\right)$ didapatkan dari hasil sebesar 0,988 atau 98,8 \% yang berarti variabilitas variabel kinerja pegawai Wilayah Kecamatan Kota Tarakan dapat dijelaskan oleh variabel kepemimpinan, budaya organisasi, lingkungan kerja dan kepuasan kerja sebesar 98,8\%, sedangkan sisanya 1,2\% dipengaruhi oleh variabel lain yang tidak diteliti.

\section{Analisis Hubungan Korelasi}

Pengaruh Langsung, Tidak Langsung dan Pengaruh Total

Tabel 3. Hasil Kesimpulan Regresi Jalur Total

\begin{tabular}{lrrrrr}
\hline \multirow{2}{*}{ Arah Hubungan } & \multicolumn{2}{c}{ Regresi } & \multicolumn{2}{c}{ Korelasi } & \multirow{2}{*}{$\varepsilon$} \\
& Beta & Sig & \multicolumn{1}{c}{ r } & Sig & \\
\hline $\mathrm{X}_{1} \rightarrow \mathrm{X}_{4}$ & 0,324 & 0,000 & 0,864 & 0,000 & 0,106 \\
$\mathrm{X}_{2} \rightarrow \mathrm{X}_{4}$ & 0,126 & 0,017 & 0,822 & 0,000 & \\
$\mathrm{X}_{3} \rightarrow \mathrm{X}_{4}$ & 0,557 & 0,000 & 0,917 & 0,000 & \\
\hline $\mathrm{X}_{1} \rightarrow \mathrm{Y}$ & 0,636 & 0,000 & 0,919 & 0,000 & 0,112 \\
$\mathrm{X}_{2} \rightarrow \mathrm{Y}$ & $-0,161$ & 0,004 & 0,719 & 0,000 & \\
$\mathrm{X}_{3} \rightarrow \mathrm{Y}$ & 0,171 & 0,029 & 0,834 & 0,000 & \\
$\mathrm{X}_{4} \rightarrow \mathrm{Y}$ & 0,313 & 0,001 & 0,886 & 0,000 & \\
\hline
\end{tabular}

\section{Pengaruh Langsung (Direct Effect)}

a. Berdasarkan pengujian regresi linier berganda persamaan kedua diperoleh standardized coefficients beta variabel kepemimpinan sebesar 0,636 sehingga berpengaruh langsung secara positif terhadap kinerja pegawai. 
b. Berdasarkan pengujian regresi linier berganda persamaan kedua diperoleh standardized coefficients beta variabel budaya organisasi sebesar $-0,161$ sehingga berpengaruh langsung secara negatif terhadap kinerja pegawai.

c. Berdasarkan pengujian regresi linier berganda persamaan kedua diperoleh standardized coefficients beta variabel lingkungan kerja sebesar 0,171 sehingga berpengaruh langsung secara positif terhadap kinerja pegawai.

\section{Pengaruh Tidak Langsung (Indirect Effect)}

a. Hasil menunjukkan bahwa kepuasan kerja mampu sebagai variabel antara pengaruh kepemimpinan terhadap kinerja pegawai. Pengaruh langsung antara kepemimpinan terhadap kinerja pegawai dengan koefisien sebesar 0,636 lebih besar dari pada pengaruh tidak langsung antara kepemimpinan melalui kepuasan kerja dengan koefisien sebesar 0,101, sehingga pengaruh langsung lebih dominan dibanding pengaruh tidak langsung.

b. Hasil menunjukkan bahwa kepuasan kerja mampu sebagai variabel antara pengaruh budaya organisasi terhadap kinerja pegawai. Pengaruh langsung antara budaya organisasi terhadap kinerja pegawai dengan koefisien sebesar-0,161 lebih kecil dari pada pengaruh tidak langsung antara budaya organisasi melalui kepuasan kerja dengan koefisien sebesar 0,039, sehingga pengaruh tidak langsung lebih dominan dibanding pengaruh langsung.

c. Hasil menunjukkan bahwa kepuasan kerja mampu sebagai variabel antara pengaruh lingkungan kerja terhadap kinerja pegawai. Pengaruh langsung antara lingkungan kerja terhadap kinerja pegawai dengan koefisien sebesar 0,171 lebih kecil dari pada pengaruh tidak langsung antara lingkungan kerja melalui kepuasan kerja dengan koefisien sebesar 0,171, sehingga pengaruh tidak langsung lebih dominan dibanding pengaruh langsung.

Tabel 4. Pengaruh Langsung dan Tidak Langsung

\begin{tabular}{lccc}
\hline \multicolumn{1}{c}{ Arah Pengaruh } & $\begin{array}{c}\text { Pengaruh } \\
\text { Langsung }\end{array}$ & $\begin{array}{c}\text { Pengaruh Tidak } \\
\text { Langsung }\end{array}$ & Total Pengaruh \\
\hline Kepemimpinan $\rightarrow$ Kinerja & 0,636 & \\
Budaya organisasi $\rightarrow$ Kinerja & $-0,161$ & \\
Lingkungankerja $\rightarrow$ Kinerja & 0,171 & $0,324 \times 0,313=$ & $0,636+0,101=0,737$ \\
Kepemimpinan $\rightarrow$ Kepuasan $\rightarrow$ Kinerja & & 0,101 & $-0,161+0,039=-0,122$ \\
& & $0,126 \times 0,313=$ & $0,171+0,174=0,345$ \\
Budaya organisasi $\rightarrow$ Kepuasan $\rightarrow$ Kinerja & 0,039 & \\
& & $0,557 \times 0,313=$ \\
Lingkungankerja $\rightarrow$ Kepuasan $\rightarrow$ Kinerja & 0,174 \\
\end{tabular}

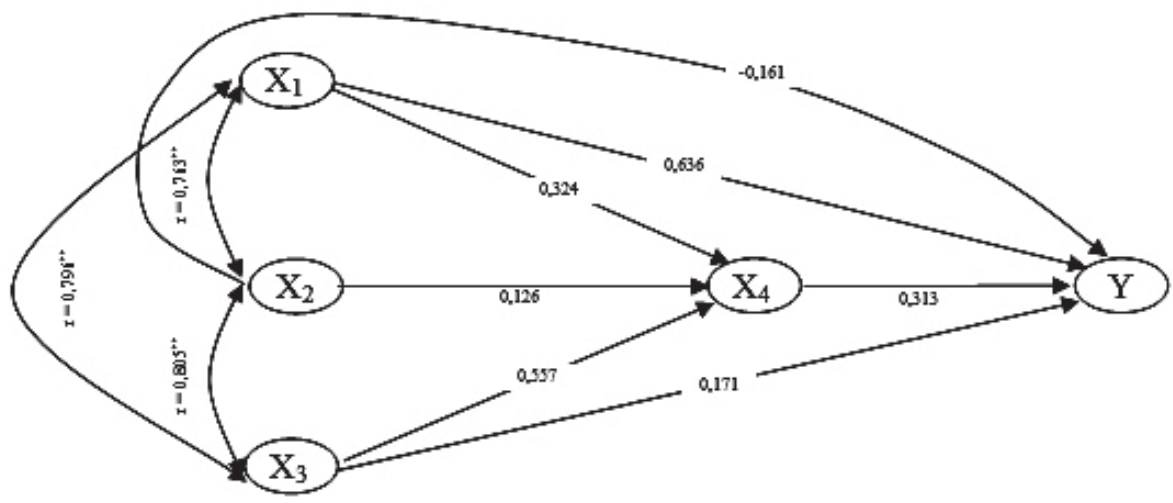




\section{Pengaruh Total (Total Effect)}

a. Berdasarkan hasil pengujian regresi linier berganda persamaan pertama dan kedua menunjukkan pengaruh total dari penjumlahan pengaruh kepemimpinan terhadap kepuasan kerja dengan pengaruh kepuasan kerja terhadap kinerja yaitu 0,737. Hasil ini menunjukkan bahwa pengaruh keseluruhan dari kepemimpinan terhadap kinerja pegawai melalui kepuasan kerja sebesar 0,737.

b. Berdasarkan hasil pengujian regresi linier berganda persamaan pertama dan kedua menunjukkan pengaruh total dari penjumlahan pengaruh budaya organisasi terhadap kepuasan kerja dengan pengaruh kepuasan kerja terhadap kinerja yaitu:-0,122. Hasil ini menunjukkan bahwa pengaruh keseluruhan dari budaya organisasi terhadap kinerja pegawai melalui kepuasan kerja sebesar 0,122 .

c. Berdasarkan hasil pengujian regresi linier berganda persamaan pertama dan kedua menunjukkan pengaruh total dari penjumlahan pengaruh lingkungan kerja terhadap kepuasan kerja dengan pengaruh kepuasan kerja terhadap kinerja yaitu:0,345. Hasil ini menunjukkan bahwa pengaruh keseluruhan dari lingkungan kerja terhadap kinerja pegawai melalui kepuasan kerja sebesar 0,345 .

\section{Pembahasan}

Hasil penelitian ini menunjukkan bahwa kepemimpinan dapat berpengaruh secara langsung dan signifikan terhadap kinerja pegawai wilayah Kecamatan Kota Tarakan, hasil ini mengindikasikan bahwa semakin meningkat gaya kepemimpinan maka menyebabkan kinerja pegawai wilayah Kecamatan Kota Tarakan juga meningkat. Hasil ini mengindikasikan semakin baik pimpinan dalam menentukan tujuan dari program organisasi; pemimpin dapat mencapai tujuan dengan bersamasama staf yang di bawahnya; pemimpin mampu mendorong pegawainya untuk saling bekerjasama dalam bertugas; pimpinan terbuka dengan pegawainya tentang visi dan misi kantor; pemimpin dapat dipercaya; pimpinan selalu mendorong pegawainya untuk mencetuskan atau mengembangkan ideide barunya; pemimpin mampu memberikan pengarahan cara kerja yang baik; pemimpin memberikan kesempatan untuk mengembangkan perbaikan rencana kantor; dan pimpinan selalu melibatkan pegawai/bawahan membuat keputusan program. Hasil penelitian ini mendukung penelitian yang dilakukan Wahyuni (2012) yang menyimpulkan bahwa kepemimpinan berpengaruh signifikan terhadap kinerja pegawai. Indriyanti dan Tjahjadi (2014), Vita (2015) yang menyimpulkan bahwa kepemimpinan berpengaruh signifikan terhadap kinerja pegawai.

Lingkungan kerja dapat berpengaruh secara langsung dan signifikan terhadap kinerja pegawai wilayah Kecamatan Kota Tarakan, hasil ini mengindikasikan bahwa semakin baik lingkungan kerja maka menyebabkan kinerja pegawai wilayah Kecamatan Kota Tarakan meningkat. Hasil ini mengindikasikan semakin baik aturan-aturan yang diterapkan membuat bekerja lebih baik, tata tertib pegawai cukup membuat nyaman; dukungan teman sejawat cukup membantu pelaksanaan tugas; sikap saling membantu dalam bekerja; dapat penghargaan insentif (imbalan); ukuran hasil pekerjaan memadai sehingga saya dapat bekerja dengan baik; selama ini penilaian hasil pekerjaan pegawai sesuai dengan kemampuan pegawainya; tidak ada diskriminasi penilaian kinerja pegawai; dan jarang terjadi ketidakcocokan dalam bekerja dengan teman sejawat. Hasilpenelitianinimendukung penelitian yang dilakukan Indriyanti dan Tjahjadi (2014), Vita (2015) yang menyimpulkan bahwa lingkungan kerja berpengaruh signifikan terhadap kinerja pegawai.

Budaya organisasi dapat berpengaruh secara langsung dan signifikan terhadap kinerja pegawai wilayah Kecamatan Kota Tarakan, hasil ini mengindikasikan bahwa semakin baik budaya organisasi maka menyebabkan kinerja pegawai wilayah Kecamatan Kota Tarakan meningkat. Hasil ini 
mengindikasikan semakin baik mekanisme kerja/terorganisasi; hubungan kerjasama antar unit-unit kerja (struktural fungsional) berjalan dengan baik; aktivitas setiap pegawai merata sesuai dengan pangkat dan jabatan; deskripsi tugas-tugas terlaksana dengan baik; semua ketentuan/peraturan dan disiplin kerja ditaati dan dilaksanakan oleh para pegawai dengan penuh tanggung jawab; keadilan dalam pembagian kompensasi; pimpinan selalu menyelesaikan masalah melalui rapat/pertemuan pegawai; besarnya kompensasi yang diberikan sesuai dengan prestasi kerjanya; tidak nampak adanya rasa sentimen sesama pegawai di kantor dalam hal pemberian kompensasi; dan pimpinan banyak mempengaruhi dan menentukan perilaku pegawai dalam mencapai tujuan kantor. Hasil penelitian ini mendukung penelitian yang dilakukan Wahyuni (2012), Indriyanti dan Tjahjadi (2014), Vita (2015) yang menyimpulkan bahwa budaya organisasi berpengaruh signifikan terhadap kinerja pegawai.

Pengaruh kepemimpinan secara tidak langsung melalui kepuasan kerja berpengaruh positif dan signifikan terhadap kinerja. Hasil ini mengindikasikan bahwa meningkatnya kepemimpinan yang disebabkan kualitas yang dimiliki oleh pribadi seorang pemimpin dan kemampuan yang dimiliki seorang pemimpin, sehingga dapat meningkatkan kepuasan kerja pegawai dengan demikian meningkatkan pula kinerja pegawai. Pengaruh budaya organisasi secara tidak langsung melalui kepuasan kerja berpengaruh negatif dan signifikan terhadap kinerja. Hasil ini mengindikasikan bahwa lemahnya budaya organisasi akan mengakibatkan pegawai tidak merasa puas dengan hasil kerjanya, sehingga dapat menurunkan kepuasan kerja pegawai dengan demikian menurunkan pula kinerja pegawai. Hasil penelitian ini sejalan dengan penelitian Indriyanti dan Tjahjadi (2014) yang menyimpulkan bahwa kepemimpinan berpengaruh signifikan terhadap kinerja pegawai tidak melalui variabel apapun.

Hasil penelitian ini menunjukkan bahwa pengaruh lingkungan kerja secara tidak langsung melalui kepuasan kerja berpengaruh positif dan signifikan terhadap kinerja. Hasil ini mengindikasikan bahwa kenyamanan dan keamanan lingkungan kerja akan membuat pegawai merasa nyaman dan aman dalam bekerja yang akan mengakibatkan pegawai lebih puas dengan hasil kerjanya, sehingga dapat menambah kepuasan kerja pegawai dengan demikian meningkatkan kinerja pegawai. Hasil penelitian ini sejalan dengan penelitian Indriyanti dan Tjahjadi (2014) yang menyimpulkan bahwa lingkungan kerja berpengaruh signifikan terhadap kinerja pegawai tidak melalui variabel apapun.

\section{E. PENUTUP}

\section{Kesimpulan}

Setelah dilakukan penelitian diperoleh kesimpulan bahwa (1) Kepemimpinan berpengaruh positif dan signifikan terhadap kepuasan kerja pegawai wilayah Kecamatan Kota Tarakan. (2) Budaya organisasi berpengaruh positif dan signifikan terhadap kepuasan kerja pegawai wilayah Kecamatan Kota Tarakan. (3) Lingkungan kerja berpengaruh positif dan signifikan terhadap kepuasan kerja pegawai Wilayah Kecamatan Kota Tarakan. (4) Kepemimpinan berpengaruh positif dan signifikan terhadap kinerja pegawai Wilayah Kecamatan Kota Tarakan. (5) Budaya organisasi berpengaruh positif dan signifikan terhadap kinerja pegawai Wilayah Kecamatan Kota Tarakan. (6) Lingkungan kerja berpengaruh positif dan signifikan terhadap kinerja pegawai Wilayah Kecamatan Kota Tarakan. (7) Kepuasan kerja berpengaruh positif dan signifikan terhadap kinerja pegawai Wilayah Kecamatan Kota Tarakan. Secara bersama-sama menunjukkan bahwa kepemimpinan, budaya organisasi, lingkungan kerja dan kepuasan kerja berpengaruh terhadap kinerja pegawai. Kepemimpinan, budaya organisasi dan lingkungan kerja mampu menjelaskan kepuasan kerja pegawai sebesar 89,4\% dan 88,8\% kinerja pegawai dijelaskan kepemimpinan, budaya organisasi, lingkungan kerja dan kepuasan kerja. Berdasarkan analisis korelasi diketahui hubungan antara kepemimpinan, 
budaya organisasi dan lingkungan kerja dengan kepuasan kerja sangat kuat dan searah artinya jika kepemimpinan, budaya organisasi dan lingkungan kerja meningkat maka kepuasan kerjapun akan meningkat. Demikian halnya hubungan antara kepemimpinan, budaya organisasi, lingkungan kerja dan kepuasan kerja dengan kinerja pegawai sangat kuat dan searah artinya jika kepemimpinan, budaya organisasi, lingkungan kerja dan kepuasan kerja meningkat maka kinerja pegawaipun akan meningkat. Hasil analisis jalur menunjukkan bahwa:(1) Kepuasan kerja terbukti sebagai variabel antara pengaruh langsung antara kepemimpinan terhadap kinerja pegawai lebih dominan dibanding pengaruh tidak langsung. (2) Kepuasan kerja terbukti sebagai variabel antara pengaruh tidak langsung budaya organisasi terhadap kinerja pegawai lebih dominan dibanding pengaruh langsung. (3) Kepuasan kerja terbukti sebagai variabel antara pengaruh tidak langsung antara lingkungan kerja lebih dominan dibanding pengaruh langsung

Keterbatasan masalah dalam penelitian ini hanya menggunakan variabel kepemimpinan, budaya organisasi, lingkungan kerja dan kepuasan kerja dalam mempengaruhi kinerja pegawai. Adanya kemungkinan variabel-variabel lain yang berpengaruh terhadap kinerja yang belum dapat dijabarkan dalam penelitian ini, misalnya motivasi kerja, semangat kerja, kedisiplinan kerja, tingkat pendidikan dan pelatihan, keterampilan dapat terjadi.

\section{Saran}

1. Hasil penelitian ini menunjukkan bahwa variabel kepemimpinan, budaya organisasi dan lingkungan kerja mempengaruhi tinggi rendahnya kinerja pegawai baik secara langsung maupun tidak langsung, dengan demikian dapat diajukan saran bagi pemerintahan khususnya tingkat kecamatan untuk memberikan perhatian khusus pada gaya kepemimpinan yang diterapkan selama ini, budaya organisasi yang berjalan serta faktor lingkungan kerjanya. Apabila ketiga variabel tersebut diperhatikan maka akan meningkatkan kinerja pegawai.

2. Sebagai pegawai pemerintahan yang mengabdi untuk memberikan pelayanan kepada publik maka perlu mencurahkan kinerjanya semaksimal mungkin, sehingga kebutuhan publik terlayani dan terpuaskan.

3. Bagi penelitian mendatang dapat dijadikan sumber ide bagi pengembangan penelitian di masa yang akan datang. Bagi pengembangan penelitian disarankan untuk menambahkan variabel lain yang dapat mempengaruhi kinerja pegawai.

\section{DAFTAR PUSTAKA}

As’ad, M., (2015). Psikologi Industri. Edisi 4. Yogyakarta: Liberty.

Baron, R. A \&Greenberg, J. (2008). Behavior in Organizations :Understanding The Human Side of Work (third edition). USA: Allyn \& Bacon.

Gibson, Invancevich, and Dbasonelly. (2009). Organization. Ninth Edition. Irwin Inc.

Handoko, T. Hani. (2010). Manajemen Personalia \& Sumberdaya Manusia. Yogyakarta: BPFE.

IndriyantidanTjahjadi. (2014). Pengaruh Budaya Organisasi, Gaya Kepemimpinan dan Lingkungan Kerja Terhadap KinerjaKaryawan. Jurnal Bisnis Akuntansi. Vol. 16, No. 1a, Is. 5. Pp 1-12

Luthans E.A.(2012). Organizational Behavior, Sixth Edition, Singapore: McGraw Hill Book Co. Mangkunegara, A.P. (2011).Manajemen Sumber Daya Manusia Perusahaan, Bandung: PT Remaja Rosdakarya. 
Mas'ud, F. (2010). Survai Diagnosis Organisasional (Konsep dan Aplikasi). Semarang: Badan Penerbit Universitas Diponegoro.

Mulyadi. (2011). Manajemen:Konsep, Manfaat, Rekayasa. Edisi Ketiga. Jakarta: Salemba Empat.

Nanus, Burt.(2012). Kepemimpinan Visioner: Menciptakan Kesadaran akan Arah dan Tujuan di dalam Organisasi. Jakarta: PT Prenhallindo.

Nitisemito, A. (2012), Management Personalia. Cetakan Kedelapan. Jakarta: Penerbit Ghalia Indonesia

Rivai, V. (2010). Kepemimpinan dan Perilaku Organisasi (Cetakan Pertama). Jakarta: PT Raja Grafindo Persada.

Sarwoto.(2011). Dasar-Dasar Organisasi dan Manajemen. Jakarta: Gahlia Indonesia.

Schein, E.H. (2011). Organizational culture and leadership. San Fransisco: Jossey-Bass.

Sedarmayanti. (2012). Manajemen Sumber Daya Manusia. Bandung: CV Mandar Maju

Siagian, P. S. (2012).Teori dan Praktek Kepemimpinan, cetakan Kelima Jakarta: Rineka Cipta.

Sudarmanto. (2012). Kinerja dan Pengembangan Kompetensi SDM (Teori, Dimensi Pengukuran dan Implementasi dalam Organisasi). Yogyakarta : Pustaka Pelajar

Sugiyono. (2012). Metode Penelitian Kuantitatif, Kualitatif dan R\&D. Yogyakarta : Alfabeta.

Supardi, A. (2011). Dasar-dasar Perilaku Organisasi (Cetakan Pertama). Yogyakarta: UII Press.

Suradji dan Martono. (2014), Ilmu dan Seni Kepemimpinan, Jakarta: Pustaka Reka Cipta.

Sutrisno, Edy.(2012). Manajemen Sumber Daya Manusia. Jakarta: Penerbit Kencana.

UU RI. (2010). Undang-Undang Republik Indonesia Nomor 32 Tahun 2010 tentang Pemerintah Daerah.

Vita, B. (2015). Pengaruh Gaya Kepemimpinan, Budaya Organisasi, Dan Lingkungan Kerja Terhadap Kinerja Guru dan Karyawan pada Yayasan Tri Asih Jakarta.Jurnal Ilmiah Penelitian,Fakultas Ekonomi Universitas Atma Jaya Yogyakarta. Pp 1-12.

Wahyuni, S. (2012). Pengaruh Kepemimpinan, Budaya Organisasi dan Motivasi Kerja Terhadap Kinerja Karyawan pada PT. Tiga Serangkai Surakarta.Naskah Publikasi Ilmiah. Fakultas Ekonomi UMS Surakarta. Pp 1-19. 
